\title{
ASPECTS OF RESEARCH WRITTEN TEXT AS AN OBJECT OF FORENCIS LINGUISTIC EXPERTISE
}

\author{
Svetlana V. Ionova \\ Volgograd State University, Volgograd, Russian Federation
}

\begin{abstract}
The article explores aspects of the study of written texts and written fixation of oral speech as the product of speech activity. The necessity of the further development of practically important topics in the study of speech works: diagnosis and identification of the language of personality created by the text; the distinction between spontaneous and written speech; the finding of lack of independence of creating written text. The area with highest demand for research in these areas is a linguistic examination of the text establishes a link between personality, level of language, communicative writing competence, characteristics, purpose and effects of her speech. Proposed overview available in the field of linguistic examination of advances showed that linguistic expertise makes full use of all the achievements of fundamental science: the concept of linguistic identity, typology of texts, literary language and spontaneous speech, the correlation between written and oral forms of expression, norms and development in the communication process, etc.; however, the disposal experts don't have a uniform, systematically organized and empirically grounded base of diagnostic features, necessary in order to fundamental knowledge in linguistics, became the basis for the development of proven technologies in solving practical problems.

Key words: applied linguistics, forensic linguistic expertise, written speech, diagnostics, identification, spontaneous speech, lack of independence of written language, creolized text.

Citation. Ionova S.V. Aspects of Research Written Text as an Object of Forencis Linguistic Expertise. Vestnik Volgogradskogo gosudarstvennogo universiteta. Seriya 2, Yazykoznanie [Science Journal of Volgograd State University. Linguistics], 2017, vol. 16, no. 2, pp. 28-38. (in Russian). DOI: https://doi.org/10.15688/jvolsu2.2017.2.3.
\end{abstract}

УДК 81'33

Дата поступления статьи: 01.02.2017

ББК 81.1 Дата принятия статьи: 24.04.2017

\section{АСПЕКТЫ ИССЛЕДОВАНИЯ ПИСЬМЕННОГО ТЕКСТА КАК ОБЪЕКТА ЛИНГВИСТИЧЕСКОЙ ЭКСПЕРТИЗЫ}

\author{
Светлана Валентиновна Ионова \\ Волгоградский государственный университет, г. Волгоград, Российская Федерация
}

\begin{abstract}
Аннотация. В статье характеризуются аспекты изучения письменных текстов и письменной фиксации устной речи как продуктов речевой деятельности. Обосновывается необходимость дальнейшей разработки практически значимых вопросов в исследовании речевых произведений: диагностика и идентификация языковых личностей по созданному ими тексту; разграничение спонтанной и подготовленной письменной речи; установление факта несамостоятельности создания письменного текста. Областью наибольшей востребованности исследований в перечисленных направлениях является лингвистическая экспертиза текста, устанавливающая связь между личностью, уровнем ее языковой, коммуникативной письменной компетенции, особенностями, целью и эффектами ее речи. Предложенный в статье обзор имеющихся в области лингвистической экспертизы достижений показал, что лингвистическая экспертиза в полной мере использует все достижения фундаментальной науки: ๓ं понятие языковой личности, типологии текстов, литературного языка и спонтанной речи, соотношения письмен근 и устной форм выражения мысли, нормы и ее развития в процессе коммуникации и др.; однако в распоряже\%ิ ии экспертов сегодня нет единообразной, систематически организованной и эмпирически обоснованной базы диагностических признаков, необходимой для того, чтобы фундаментальные знания, накопленные в языкознании, стали основой для разработки апробированных технологий решения практических задач.
\end{abstract}


Ключевые слова: прикладная лингвистика, лингвистическая экспертиза, письменная речь, диагностика, идентификация, спонтанная речь, несамостоятельность письменной речи, креолизованный текст.

Цитирование. Ионова С. В. Аспекты исследования письменного текста как объекта лингвистической экспертизы // Вестник Волгоградского государственного университета. Серия 2, Языкознание. - 2017. - Т. 16, № 2. - C. 28-38. - DOI: https://doi.org/10.15688/jvolsu2.2017.2.3.

Все лингвистические традиции создавались для решения конкретных практических задач.

В.М. Алпатов

Введение. Обосновывая тезис, вынесенный в эпиграф данной статьи, В.М. Алпатов отмечал, что человеку свойственно не замечать язык, на котором он говорит, до тех пор пока перед ним не появляются проблемы, связанные с осуществлением речевой практики и пониманием значимой информации. Данное наблюдение справедливо для коммуникации носителей различных языков; для задач обучения языкам; для ситуаций значительных расхождений между разговорным и литературным вариантами языка, скопления речевых ошибок, приводящих к непониманию собеседника; для толкования канонических текстов; для этимологии как восстановления «истинного» слова, забытого людьми и др. [Алпатов, 1999, с. 11, 17-20].

С усложнением социальных форм коммуникации необходимость осмысления законов языка и выработки рекомендаций по совершенствованию речевого взаимодействия привела к появлению таких сфер языковой и речевой практики, которые соединили в себе результаты наблюдений носителей языка и теоретиков языкознания: составление словарей, грамматик; делопроизводство; терминоведение; риторика; стихосложение др.

В наше время потребность в упрощении процессов механической обработки массивов информации, в том числе ее систематизации, автоматизации поиска, перевода на другие языки, аннотирования, стала стимулом к появлению компьютерной лингвистики; выработка оптимальных моделей управления массами и необходимость распознавания способов воздействия на сознание адресатов - к обоснованию психолингвистического подхода как объяснительного инструмента науки и др.

Лингвистическая экспертиза - особая область прикладных исследований, которая возникла в связи с потребностями юридической практики и сегодня функционирует в качестве самостоятельного рода экспертной деятельности и вида судебных доказательств, являясь одной из молодых отраслей гуманитарной экспертизы ${ }^{1}$. Перед экспертом-лингвистом ставятся задачи, которые предполагают и юридический аспект исследования. Предмет изучения при этом составляют юридически значимые факты, устанавливаемые на основе анализа продуктов речевой деятельности - письменных и устных текстов.

Научные и экспертные исследования. Лингвистическая экспертиза представляет собой наукоемкую отрасль прикладной лингвистки: она является таким видом деятельности специалиста, который связан с вынесением компетентного заключения по вопросам практики в определенной сфере деятельности с опорой на результаты научных исследований, имеющихся в данной сфере ${ }^{2}$. В то же время экспертная деятельность не тождественна научной деятельности как процессу познания объективной действительности, а основывается на его достижениях новых знаниях, полученных в результате всестороннего и достоверного изучения объектов, процессов или явлений при помощи имеющихся в науке принципов и методов познания. Лингвистическая экспертиза - это привлечение знаний специалиста в области лингвистики для решения практических задач, которое не предполагает «изобретения», «открытия» чего-то нового.

Экспертизу принято рассматривать как социальную технологию, обладающую рядом специфических черт: по своему технологическому содержанию она представляет собой исследование, которое связано с решением социально значимых задач; осуществляется по заказу инстанций, принимающих решение и использующих заключение экспертов при выработке решения; итогом экспертизы становится ответственное экспертное заключение, имеющее решающее значение для принятия 
решения соответствующими инстанциями; экспертное заключение носит доказательный характер; используемая в нем аргументация должна быть рационально выраженной в интерсубъективной, то есть доступной общественности, форме [Тульчинский, 2008; Экспертиза в современном мире, 2006].

В то же время в практике решения экспертных задач возникают новые области научных исследований, актуализируются малоизученные аспекты известных объектов изучения, совершенствуются исследовательские технологии, определяются нерешенные или недостаточно обоснованные в науке сферы описания языка и речи. Так, лингвистическая теория языковой личности основывается на следующих тезисах: языковая личность (личность, взятая в ее отношении к языку и речи; языковая личность, «стоящая за текстом») проявляется в способностях и характеристиках человека, обусловливающих создание и восприятие им речевых произведений (текстов), которые различаются а) степенью структурно-языковой сложности, б) глубиной и точностью отражения действительности, определенной целевой направленностью; за каждой языковой личностью стоит множество производимых ею текстов (дискурсов) [Cедов, 1996]. Однако анализ текстов, функционирующих в юридически значимых ситуациях, показывает не меньшую значимость следующих положений, вытекающих не только из лингвистической теории, но и из экспертной практики: за каждым текстом могут стоять разные личности, являющиеся его авторами, уподобляющиеся им, разуподобляющие авторство или иными способами участвующие в текстуализации выражаемой информации; речевое поведение личности может отражать неосознаваемую часть речевой деятельности, опыт, который в результате многократного повторения ушел вглубь сознания [Матвеева, 1999], а также осознаваемую и контролируемую ее часть, лежащую в основе записи чужого текста, его редактирования, частичного заимствования, стилизации [Ионова, 2015]. Учитывая перечисленные особенности создания речевых произведений, следует говорить о тесном взаимодействии и взаимообогащении лингвистической науки и экспертной практики.
Лингвистическая экспертиза не тожественна экспертизе филологической, несмотря на общий объект изучения этих областей знания. Филологическая экспертиза представляет собой научно-экспертное исследование, в рамках которого возможно ответить на вопросы, относящиеся к фактам языка и литературы, например: установление происхождения, первоначального значения, переносного значения, исторических изменений того или иного слова / выражения; установление обстоятельств происхождения, территориальных или социальных отличий использования имен, фамилий, названий и других имен собственных; выявление смыслового содержания названий фирм, организаций, предприятий, кафе, ресторанов, газет, журналов, гостиниц и других имен собственных. Подобные исследования, имея заказчика в лице представителей нефилологической сферы (например, музеев, архивов, издательств, политических и общественных организаций, редакций СМИ и др.), могут быть не связанными с юридическими инстанциями и не нормироваться законодательством об экспертной деятельности. Такие виды работ, как правило, проводят специалисты, а их заключения имеют статус лингвистического исследования, в то время как судебные лингвистические экспертизы в нашей стране (по сложившейся традиции и разработанному законодательству об экспертной деятельности) проводятся только по назначению следственных и судебных органов ${ }^{3}$.

От нормы языка к живому человеческому общению. Возможность исследования письменных произведений в экспертных целях базируется на методологических положениях лингвистики, которые формировались на протяжении всей истории этой науки и реализовались в полной мере в рамках антропоцентрического языкознания и функционального подхода к рассмотрению речевых произведений носителя языка.

Известно, что функциональный подход в лингвистике не сразу получил признание и легитимность наряду со структурным подходом к языку. Филологическая традиция исследования канонических текстов, первоначально сложившаяся как задача толкования текстов на «не до конца понятном языке» в западной традиции, сформировала представления о нор- 
ме как языковой модели, «извлеченной» из канонического произведения. Расхождения между языковым идеалом и реальной языковой практикой расценивались как «порча языка», поскольку человек «не может изменить или усовершенствовать божий дар, но может полностью или частично его забыть или испортить» [Алпатов, 1999, с. 20]. В структурном языкознании нормативный подход трансформировался в теоретическую декларацию об объективно-исторической и самоорганизующейся сущности языка, которая является критерием истинности при формировании норм [Данеш, 1987; Матезиус, 1967]. При таком подходе критерием правильности также выступает некий отвлеченный от речи «образец», однозначно предписываемый ортологический меморандум для облегчения (однозначного) выбора языкового варианта [Голев].

Однако уже в недрах структурного языкознания зарождался иной, функциональный, взгляд на норму, который выводил отклонения от нее из фундаментальных свойств функционирования языка [Фрей, 2006] и особенностей самого носителя языка - его психологической и рече-поведенческой специфики [Щерба, 1974]. По мнению Л.В. Щербы, в работах лингвистов обычно отсутствуют примеры неудачных высказываний, в то время как они формируют «весьма важную составную часть языкового материала» [Щерба, 1974, c. 36]. «Отрицательный языковой материал» (термин Л.В. Щербы) представляет эвристическую ценность для антропоцентрических исследований в лингвистике, где рассмотрение любых отклонений от «правильного» языка в речевой практике его носителей связывается с проявлением «человеческого фактора» в языке и определяет базовые принципы изучения продуктов речевой деятельности личности. При помощи подобных несистемных и ненормативных признаков ученый получает доступ к таким ненаблюдаемым явлениям, как психика человека, цели его действий, национальная, социальная, территориальная принадлежность человека, его общественный статус, коммуникативная роль в определенной ситуации общения и др. Язык «разоблачает» человека даже в том случае, если тот предпринимает попытки скрыть подобные характеристики невербальными средствами.
Экспертное исследование письменных материалов. Методологические основы современной антропоцентрической лингвистики используются в лингвистической экспертизе в качестве базовых принципов исследования письменной речи: а) как вторичной системы кодирования мысли по отношению к устной речи; б) воспринимаемой зрительно, развертывающейся линейно; в) содержащей служебные знаки графической системы - знаки письма, отсутствующие в устной речи; г) готовящейся заранее, продумываемой, обрабатываемой и редактируемой автором, в том числе по ходу написания текста; д) отличающейся от устной речи большей сложностью синтаксиса, наличием большего количества отвлеченной лексики, а также лексики терминологической, интернациональной, профессиональной.

Объектом экспертного исследования выступают письменные материалы разного типа: газетные и журнальные публикации; скрипты дикторской речи; скрипты устной речи участников юридически значимых коммуникативных ситуаций; книги; документы, имеющие юридическую силу (договоры, расписки); материалы дела, по которому проводится лингвистическая экспертиза (показания свидетелей, заявления, протоколы и пр.); тексты интернет-коммуникации (форумов, блогов, социальных сетей); комбинированные (креолизованные) тексты. Предметом являются факты и обстоятельства, устанавливаемые на основе исследования закономерностей существования и использования естественного или искусственного языка его носителями.

В отличие от экспертизы звучащей речи, в ходе которой выявляются акустические характеристики речевых высказываний, в том числе для определения автора речевого сообщения, письменный текст анализируется по целому ряду признаков: графических, грамматических, семантических, прагматических, что предполагает использование традиционных методов и подходов, обоснованных в лингвистической науке.

Спорным в лингвистической экспертизе письменной речи является возможность извлекать из письменного текста информацию, важную для решения практических задач, поскольку этот вид речевых произведений при- 
нято считать результатом обработки знания и представления его в социально приемлемых формах. В связи с этим делается вывод о минимальной степени ситуативности письменного текста, об опосредованном характере отражения в нем авторских черт, о невозможности решения диагностических задач на письменном материале. В то же время появление новых «форм овеществления» текста в современной устно-письменной коммуникации, опосредованной компьютером, позволяет понимать под письменной речью и такую ее разновидность, как естественная письменная речь, то есть речевая деятельность и ее результат (тексты), которая занимает свое место в парадигме, построенной по координатам «устная / письменная» и «естественная / искусственная (искусная)» речь [Лебедева, 2001]. Таким образом, по отношению к письменному речевому произведению целесообразно применение двух подходов, сформулированных О.Б. Сиротининой: текст как сознательно организованная речь и текст как реальная организация речевого замысла [Сиротинина, 1994, с. 105].

Идентификация и диагностика личности. Несмотря на то что письмо - «та область неопределенности, неоднородности и уклончивости, где теряются следы нашей субъективности» [Барт, 1994, с. 384], письменные тексты используются в качестве материала для установления их авторства. В лексическом и грамматическом отношении письменная реализация речи характеризуется соблюдением литературных норм языка особым отбором лексики и фразеологии, обработанным синтаксисом, что в большой степени нейтрализует свободу выражения автора и затрудняет диагностирование его личностных черт. В то же время каждый индивидуум реализует себя в языке, представляя определенный социальный вариант нормы. Осуществляя тот или иной отбор средств из фондов национального языка, пишущий идентифицирует себя как личность, принадлежащую определенной социальной группе, что в свою очередь дает возможность установить уровень языковой компетенции пишущего [Розанова, 2005].

Установление принадлежности автора к определенной языковой, национально-культур- ной, социокультурной группе в зависимости от его образования, профессии, социально-демографических характеристик, уровня сложившейся языковой и письменной компетенций решается в рамках диагностических задач. Массивы текстов, создаваемых типичными носителями языка с разными социолингвистическими характеристиками, могут служить своеобразным синергетически организованным прототипом, воплощающим нормы письменности для разных групп пишущих. При этом спонтанные утилитарные тексты для целей диагностики представляют не меньшую ценность, чем художественные и публицистические тексты, создаваемые элитарными языковыми личностями, поскольку отражают письменную речевую практику среднего носителя языка различных социокультурных групп: как пишут школьники; как пишут математики; как пишут юристы; как пишут старики; как пишут по-русски иностранцы; как пишут слабослышащче люди; как пишут люди, страдающие психологическими расстройствами; как пишут люди в состоянии эмоциональной напряженности; как пишут люди в среде шумовых помех и др. Языкознание могло бы более эффективно отвечать на запросы практики, решая следующие проблемы: представитель какой соииокультурной группы является автором данного текста? какова вероятность того, что данный текст был написан иностранием? может ли автором данного текста быть ребенок / школьник? и др.

Письменные тексты, в отличие от устных, характеризуются более устойчивыми и менее случайными чертами авторства.

Установление индивидуальных черт личности по данным языка - задача, связанная с идентификацией личности. Идентификация (от лат. identificare «тот же») - отождествление, то есть решение вопроса о системе единичных, уникальных речевых характеристик личности, ее идиостиля. Большая часть языковедов, работающих в этой области, акцентируют внимание на изучении персонотекстов - разновидностей речевого произведения, в которых через языковые характеристики репрезентируется языковой потенциал личности [Напреенко, 2015].

В экспертной деятельности идентифицировать - значит извлечь из сходного матери- 
ала единичные, различительные признаки. Основными методологическими принципами исследования при этом являются следующие положения, доказанные в современной науке: а) для каждого человека характерен уникальный комплекс особенностей речевого поведения, который может быть опознан, а знания о нем применены для идентификации личностных черт; б) нахождение или опровержение наличия черт авторства определенного лица основывается исключительно на сравнении прецедентов использования его языка в оригинальных письменных источниках.

Известно, что даже в ситуации составления нормированных документов и соблюдения кодифицированных норм русского языка возможны проявления личностных черт пишущего, позволяющие одно и то же содержание высказать по-разному. Это такие признаки, которые связаны со следующими особенностями письменной текстовой деятельности: а) индивидуальная совокупность письменно-речевых навыков автора (проявляется преимущественно на уровне лексико-фразеологических единиц) [Наумов, 2006]; б) факторы, расшатывающие норму - непоследовательное, ошибочное использование норм (проявляется преимущественно на уровне применения норм орфографии, пунктуации, норм сочетаемости, образования форм слов и предложений) [Рахилина, 2014]; в) вкрапления творческого, индивидуального стиля пишущего (проявляется на лексико-фразеологическом и синтаксическом уровнях) [Матвеева, 1999].

Процедура анализа языковых особенностей текста, принятая в лингвистической экспертологии, включает следующие аспекты изучения его особенностей: 1) анализ графической реализации; 2) анализ лексико-фразеологических особенности; 3 ) анализ грамматических особенностей; 4) анализ стилистических особенностей. При наличии признаков на каком-либо одном или нескольких уровнях анализа решается вопрос об их релевантности: массовости, устойчивости, различающей способности.

Разграничение подходов к исследованию речевой деятельности личности с позиций диагностики и идентификации предполагает ориентацию на разные лингвистические подходы, постановку различных научных задач и применение различающихся исследовательских процедур.

Подготовленность иесамостоятельность письменной речи. Подготовленность письменной речи в лингвистике воспринимается как ее естественное свойство, которое согласуется с фундаментальными текстообразующими категориями: информативностью, интенциональностью, адресованностью [Гальперин, 1981, с. 6-18 и др.], воспроизводимостью [Адмони, 1994, с. 9, 21]. Письменная речь понимается как явление социальное, основывающееся на учете и выполнении ее автором системы норм и правил, общих для всех пишущих, поэтому для письменной речи всегда характерна определенная степень подготовленности [Ионова, 2016]. В экспертной практике данное свойство текста имеет иной прагматический смысл, который противопоставляет понятие подготовленности таким понятиям, как спонтанность, естественность, самостоятельность письма. Подготовленная речь в ее юридическом значении подразумевает определенную степень ее рефлексируемости и автоматизма: заученность, неестественность, несамостоятельность. Е.И. Галяшина выделяет следующие разновидности речи по степени ее подготовленности: не подготовленная заранее (спонтанная) речь - квазиспонтанная речь - подготовленная заранее речь [Галяшина, 2003, с. 96].

Объектами экспертного исследования для определения указанных признаков выступают произведения, полученные в результате таких видов письменной деятельности автора, как списывание заранее известного текста; списывание заранее не известного текста; составление по памяти выученного заранее письменного текста; письменная речь под диктовку; изложение письменного текста; письменное ичтирование письменного текста («своего» или «чужого»); составление текста по шаблону, заполнение бланков; написание ответов на заранее поставленные вопросы; составление самостоятельного текста и др. [Галяшина, 2003, с. 98-100]. В лингвистическом плане данные разновидности письменной активности предполагают умение пишущего облекать содержание в разные формы: сочи- 
нения, подробного или сжатого изложения, списывания, заполнения пропусков. Естественная письменная речь основывается на таких видах компетенций автора речевого произведения, как его языковая компетенция, речевой опыт, компетенция в области норм составления текстов, знания о видах и жанpax текстов, стилистические навыки. Чем выше уровень компетенций, тем сложнее определить степень подготовленности речи пишущего.

Методология исследования письменных текстов в аспекте спонтанности / подготовленности определяется положениями, обоснованными в научной литературе по лингвистике текста, лингвистике речи, психолингвистике, экспертологии: а) при выявлении противопоставлений спонтанной и подготовленной письменной форм речи доказательству подвергаются признаки спонтанной письменной речи, поскольку письменная форма порождения речи сама по себе предопределяет наличие хотя бы минимальной степени ее подготовки («мысленного проговаривания»); б) при невозможности однозначного отнесения текста к спонтанному дискурсу (недостаточно признаков) принимается решение о возможной его подготовке; в) при отсутствии признаков спонтанной письменной речи возможно выявление меры подготовленности текста [Комиссаров, 2001].

В реальной речевой коммуникации преобладает спонтанная речь, она является основной, доминирующей, по сравнению с подготовленной речью [Бондарко, 2001, с. 17], однако в юридически значимых ситуациях существенными становятся признаки подготовленности речи, которые способны раскрыть важные обстоятельства коммуникативного поведения личности, дифференцировать естественные проявления его психики (состояние эмоциональной напряженности, растерянность, страх) или наличие усложненных коммуникативных тактик (использование кодового языка, иносказательность речи, сокрытие информации, фантазирование).

Другим объяснением наличия признаков подготовленности, неестественности в письменной речи человека может служить ее несамостоятельность, которая связана с возможностью пишущих стилизовать и нейтра- лизовать черты иной языковой личности при помощи набора языковых средств и речевых приемов, а также участия иных лиц (помимо автора) в составлении текста, ставшего объектом лингвистической экспертизы. В соответствии с указанными ситуациями можно выделить следующие виды авторской позиции в письменном тексте ${ }^{4}$ :

а) самостоятельная позиции автора позиция, при которой он является единственным исполнителем, фактически создавшим исследуемый текст; в тексте отсутствует разделение позиций автора и составителя текста; позиция автора - открытая (его имя заявлено в тексте как имя автора), связана с позиционированием себя как создателя текста (см. авторские и анонимные тексты);

б) несамостоятельная позиция автоpa - позиция, которая допускает участие иного лица в создании текста, не заявляющего себя в качестве автора, но способствующего формированию оптимального в данной ситуации речевого произведения; основными действиями пишущих являются самопрезентация авторов в тексте, смешение их черт (см., например, частичная запись под диктовку; запись предварительно составленной кем-то речи; редактирование авторского текста);

в) симулируемая позииия автора - позиция, которая допускает составление текста лицом, не являющимся автором, но уподобляющимся автору (стилизованные тексты, написанные от имени иного лица с указанием его авторства).

Установление признаков спонтанности / подготовленности, самостоятельности / несамостоятельности написания текста в лингвистической экспертизе позволяют решить нелингвистические задачи, возникающие в ходе следственных действий или в судебной практике: отказ фигурантов дела от показаний в связи с объявленным вмешательством представителей правоохранительных органов в составление официального авторского текста; наличие особых психологических состояний пишущего в момент написания текста, способных повлиять на его составление; написание текстов от имени лица, указанного в качестве автора и др.

Заключение. Краткий обзор актуальных проблем современной лингвистической экс- 
пертизы в данной статье показал, что лингвистическая экспертиза в полной мере использует все достижения фундаментальной науки: понятие языковой личности, типологии текстов, литературного языка и спонтанной речи, соотношения письменной и устной форм выражения мысли, нормы и ее развития в процессе коммуникации и др. В то же время проблема состоит в том, что в распоряжении экспертов сегодня нет единообразной, систематически организованной и эмпирически обоснованной базы диагностических признаков, необходимой для того, чтобы фундаментальные знания, накопленные в языкознании, стали основой для разработки апробированных технологий решения практических задач. Потребности экспертной практики и других прикладных сфер лингвистики могут послужить ориентиром при обосновании тематики научных исследований и разработке новых подходов и частных методик науки о языке.

\section{ПРИМЕЧАНИЯ}

${ }^{1}$ Приказ Министерства юстиции РФ от 9 марта 2006 г. № 36; добавление в приказ от 14 мая 2003 г. № 114 «Об утверждении Перечня родов (видов) экспертиз, выполняемых в государственных судебно-экспертных учреждениях Министерства юстиции Российской Федерации».

${ }^{2}$ Слово экспертиза в русском языке трактуется как «рассмотрение, исследование каких-л. вопросов, решение которых требует специальных знаний в области науки, техники, искусства и т. д.» (Словарь русского языка : в 4 т. / РАН, Ин-т лингвистических исследований ; под ред. А. П. Евгеньевой. 4-е изд., стер. - М. : Рус. яз : Полиграфресурсы, 1999. - T. IV. - C. 751).

3 См., например, Федеральный закон от 31 мая 2001 г. № 73-Ф3 «О государственной судебно-экспертной деятельности в Российской Федерации» (с изменениями и дополнениями).

${ }^{4}$ Под автором понимается лицо, сочинившее, создавшее текст и заявившее свое авторство в виде обозначения своего имени. В юридическом понимании автор - лицо, творческим трудом которого создано произведение в области науки, литературы или искусства. Такое произведение охраняется авторским правом (Большой юридический словарь / под ред. А. Я. Сухарева. - 3-е изд., доп. и перераб. - М. : ИНФРА-М, 2007. -С. 8); в литературоведении автор (от лат. au(c)tor - создатель): 1) биографический А., писатель; 2) А. - создатель (творец) произведения литературы, чьи представления о мире и человеке отражаются во всей структуре создаваемого им произведения (Литературный энциклопедический словарь / под общ. ред. В. М. Кожевникова, П. А. Николаева ; редкол.: Л. Г. Андреев, Н. И. Балашов, А. Г. Бочаров [и др.]. М. : Сов. энциклопедия, 1987.- С. 12).

\section{СПИСОК ЛИТЕРАТУРЫ}

Адмони, В. Г. Система форм речевого высказывания / В. Г. Адмони. - СПб. : Наука, 1994. $153 \mathrm{c}$.

Алпатов, В. М. История лингвистических учений / В. М. Алпатов. - 2-е изд., испр. - М. : Языки русской культуры, 1999. - 368 с.

Барт, Р. Смерть автора / Р. Барт // Избранные работы: Семиотика. Поэтика / Р. Барт. - М. : Прогресс : Универс, 1994. - С. 384-391.

Бондарко, Л. В. Спонтанная речь и организация системы языка / Л. В. Бондарко // Бюллетень фонетического фонда русского языка № 8 «Фонетические свойства русской спонтанной речи» / под ред. Л. В. Бондарко, М. Краузе. - СПб. : Бохум, 2001. Вып. 8. - С. 17-23.

Гальперин, И. Р. Текст как объект лингвистического исследования / И. Р. Гальперин. - М. : Наука, 1981. - 140 с.

Галяшина, Е. И. Основы судебного речеведения / Е. И. Галяшина / под ред. проф. М. В. Горбаневского. - М. : СТЭНСИ, 2003. - 236 с.

Голев, Н. Д. Современная русская ортология: концепция, содержание и программа курса на филологическом факультете / Н. Д. Голев // Сибирская ассоциация лингвистов-экспертов. - Электрон. текстовые дан. - Режим доступа: http://siberiaexpert.com/publ/3-1-0-10. - Загл. с экрана.

Данеш, Ф. Позиции и оценочные категории при кодификации / Ф. Данеш // Новое в зарубежной лингвистике. Вып. 20: Теория литературного языка в работах ученых ЧССР. - М. : Прогресс, 1987. - C. 281-295.

Ионова, С. В. Корпусы письменных спонтанных текстов и их значение для лингвистики идентификации / С. В. Ионова // Теоретические и прикладные аспекты корпусных методов изучения текстов : материалы науч.-практ. семинара (Волгоград, 5-6 нояб. 2015 г.). - Волгоград : Изд-во ВолГУ, 2015. C. 81-88.

Ионова, С. В. Признаки подготовленности письменной речи / С. В. Ионова // Актуальные проблемы комплексной судебной психолого-лингвистической экспертизы : Всерос. науч.-практ. семинар с междунар. участием (Ростов-на-Дону, 6-9 июня 2016 г.). М. ; Ростов н/Д, 2016. - С. 38-44. 
Комиссаров, А. Ю. Криминалистическое исследование письменной речи / А. Ю. Комиссаров. М. : ЭКЦ, 2001.-129 c.

Лебедева, Н. Б. Естественная письменная русская речь: проблемы изучения / Н. Б. Лебедева // Русский язык: исторические судьбы и современность = Russian language: its historical destiny and present state : тр. и материалы Междунар. конгр. исследователей рус. яз. (Москва, 13-16 марта 2001 г.). - М. : Изд-во МГУ, 2001. - С. 260-261.

Матвеева, Г. Г. Диагностирование личностных свойств автора по его речевому поведению / Г. Г. Матвеева. - Ростов н/Д : Изд-во Дон. юрид. ин-та, 1999. - 82 с.

Матезиус, В. О необходимости стабильности литературного языка / В. Матезиус // Пражский лингвистический кружок : сб. ст. - М. : Прогресс, 1967. - С. 378-393.

Напреенко, Г. В. Лексико-квантитативное моделирование языковой личности в идентификационном аспекте (на материале русскоязычных интернет-дневников) : дис. ... канд. филол. наук / Напреенко Галина Викторовна. - Кемерово, 2015. - 230 с.

Наумов, В. В. Лингвистическая идентификация личности / В. В. Наумов. - М. : КомКнига, 2006. $240 \mathrm{c}$

Рахилина, Е. В. Грамматика ошибок: в поисках констант / Е. В. Рахилина // Язык. Константы. Переменные $=$ Language. Constants. Variables : памяти Александра Евгеньевича Кибрика / редкол.: В. А. Плунгян (гл. ред.) [и др.]. - СПб. : Алетейя, 2014. - C. 87-95.

Розанова, С. П. Психология ошибки / С. П. Розанова // Теоретические и методические основы технологии предвузовского обучения российских и иностранных студентов : материалы Всерос. конф. - М. : Изд-во РУДН, 2005. - С. 292-297.

Седов, К. Ф. Типы языковых личностей и стратегии речевого поведения (о риторике бытового конфликта) / К. Ф. Седов // Вопросы стилистики. Вып. 26. Язык и человек. - Саратов : Изд-во Сарат. ун-та, 1996. - С. 8-14.

Сиротинина, О. Б. Тексты, текстоиды, дискурсы в зоне разговорной речи / О. Б. Сиротинина // Человек - текст - культура. - Екатеринбург : Полиграфист, 1994. - С. 105-124.

Тульчинский, Г. Л. Гуманитарная экспертиза как социальная технология / Г. Л. Тульчинский // Вестник Челябинской государственной академии культуры и искусств. - 2008. - № 4 (16). - С. 38-51.

Фрей, А. Грамматика ошибок / А. Фрей. M. : URSS, 2006. - 304 c.

Щерба, Л. В. О трояком аспекте языковых явлений и об эксперименте в языкознании / Л. В. Щерба // Языковая система и речевая деятельность. Л. : Наука, 1974. - С. 24-39.
Экспертиза в современном мире: от знания к деятельности / под ред. Г. В. Иванченко, Д. А. Леонтьева. - М. : Смысл, 2006. - 454 с.

\section{REFERENCES}

Admoni V.G. Sistema form rechevogo vyskazyvaniya [The System of Speech Forms]. Saint Petersburg, Nauka Publ., 1994. 153 p.

Alpatov V.M. Istoriya lingvisticheskikh ucheniy [History of Linguistic Studies]. Moscow, Yazyki russkoy kultury Publ., 1999. 368 p.

Bart R. Smert avtora [The Authors Death]. Izbrannyye raboty: Semiotika. Poetika [Selected Works: Semiotics. Poetics]. Moscow, Progress Publ.; Univers Publ., 1994, pp. 384-391.

Bondarko L.V. Spontannaya rech i organizatsiya sistemy yazyka [Spontaneous Speech and Organization of the Language System]. Bondarko L.V., Krauze M., eds. Byulleten foneticheskogo fonda russkogo yazyka № 8 "Foneticheskie svoystva russkoy spontannoy rechi» [Bulletin of the Phonetic Fund of the Russian Language no. 8 "Phonetic Properties of Spontaneous Russian Speech"]. Saint Petersburg, Bohum Publ., 2001, iss. 8, pp. 17-23.

Galperin I.R. Tekst kak obyekt lingvisticheskogo issledovaniya [The Text as Object of Linguistic Research]. Moscow, Nauka Publ., 1981. 140 p.

Galyashina E.I. Osnovy sudebnogo rechevedeniya [Basics of Forensic Speech Study]. Moscow, STENSI Publ., 2003. 236 p.

Golev N.D. Sovremennaya russkaya ortologiya: kontseptsiya, soderzhanie i programma kursa na filologicheskom fakultete [Modern Russian Orthology: Conception, Content and Course Programme at the Faculty of Philology]. Sibirskaya assotsiatsiya lingvistov-ekspertov [Siberian Association of Linguists-Experts]. URL: http://siberia-expert.com/ publ/3-1-0-10.

Danesh F. Pozitsii i otsenochnye kategorii pri kodifikatsii [Positions and Evaluative Categories at Codification]. Novoe $v$ zarubezhnoy lingvistike. Vyp. 20: Teoriya literaturnogo yazyka $v$ rabotakh uchenykh ChSSR [The New in Foreign Linguistics. Vol. 20: Theory of Literary Language in the Works of Scholars of Czechoslovakia]. Moscow, Progress Publ., 1987, pp. 281-295.

Ionova S.V. Korpusy pismennykh spontannykh tekstov i ikh znachenie dlya lingvistiki identifikatsiy [Corpus of Spontaneous Written Texts and Their Significance for Identification Linguistics: Proceedings of Scientific and Practical Seminar]. Teoreticheskie $i$ prikladnye aspekty korpusnykh metodov izucheniya tekstov: materialy nauchno-prakticheskogo seminara (Volgograd, 5-6 noyabrya 2015 g.) 
[Theoretical and Applied Aspects of Basic Methods for the Study of Texts: Materials of Scientific and Practical Seminar (Volgograd, November 5-6, 2015)]. Volgograd, Izd-vo VolGU, 2015, pp. 81-88.

Ionova S.V. Priznaki podgotovlennosti pismennoy rechi [Signs of Written Speech Preparedness]. Aktualnyye problemy kompleksnoy sudebnoy psikhologo-lingvisticheskoy ekspertizy: Vserossiyskiy nauchno-prakticheskiy seminar $s$ mezhdunarodnym uchastiem (Rostov-na-Donu, 69 iyunya 2016 g.) [Current Problems of Complex Judicial Psycho-Linguistic Examination: All-Russian Scientific and Practical Seminar with the International Participation (Rostov-on-Don, June 6-9, 2016]. Moscow, Rostov-on-Don, 2016, pp. 34-44.

Komissarov A.Yu. Kriminalisticheskoe issledovanie pismennoy rechi [Forensic Examination ofWritten Speech]. Moscow, EKTs Publ., 2001. 129 p.

Lebedeva N.B. Estestvennaya pismennaya russkaya rech: problemy izucheniya [Natural Written Russian Speech: Problems of Study]. Russkiy yazyk: istoricheskie sudby i sovremennost: tr. i materialy Mezhdunar. kongr. issledovateley rus. yaz. (Moskva, 13-16 marta 2001 g.) [The Russian Language: Historical Destiny and Modernity: Works and Materials of the International Congress of Russian Researchers (Moscow, March 13-16, 2001]. Moscow, Izd-vo MGU, 2001, pp. 260-261.

Matveeva G.G. Diagnostirovanie lichnostnykh svoystv avtora po ego rechevomu povedeniyu [Diagnosis of Personal Characteristics of the Author by Their Speech Behavior]. Rostov-on-Don, Izd-vo Donskogo yurid. in-ta, 1999. $82 \mathrm{p}$.

Matezius V. O neobkhodimosti stabilnosti literaturnogo yazyka [On the Need for Stability of the Literary Language]. Prazhskiy lingvisticheskiy kruzhok: sb. st. [The Prague Linguistic Circle: Collected Articles]. Moscow, Progress Publ., 1967, pp. 378-393.

Napreenko G.V Leksiko-kvantitativnoe modelirovanie yazykovoy lichnosti $v$ identifikatsionnom aspekte (na materiale russkoyazychnykh internet-dnevnikov): dis. ... kand. filol. nauk [Lexical and Quantitative Modeling of Linguistic Identity in the Identity Aspect (on the Material of Russian Internet Diaries). Cand. philol. sci. diss.]. Kemerovo, 2015. 230 p.
Naumov V.V. Lingvisticheskaya identifikatsiya lichnosti [Linguistic Identity of a Person]. Moscow, KomKniga Publ., 2006. 240 p.

Rakhilina E.V. Grammatika oshibok: v poiskakh konstant [Grammar of Errors: in Search of Constants]. Plungyan V.A., et al. (eds.). Yazyk. Konstanty. Peremennye: pamyati Aleksandra Evgenyevicha Kibrika [Language. Constants. Variables: in Memory of A.E. Kibrik]. Saint Petersburg, Aleteya Publ., 2014, pp. 87-95.

Rozanova S.P. Psikhologiya oshibki [The Psychology of Error]. Teoreticheskie i metodicheskie osnovy tekhnologii predvuzovskogo obucheniya rossiyskikh $i$ inostrannykh studentov: Materialy Vserossiyskoy konferentsii [Theoretical and Methodological Foundations of the Technology of pre-University Training of Russian and Foreign Students. Materials of the All-Russian Conference]. Moscow, Izd-vo RUDN, 2005, pp. 292-297.

Sedov K.F. Tipy yazykovykh lichnostey i strategii rechevogo povedeniya (o ritorike bytovogo konflikta) [Types of Linguistic Personalities and Strategies of Speech Behavior (on the Rhetoric of Domestic Conflict)]. Voprosy stilistiki. Vyp. 26. Yazyk i chelovek [Stylistics Issues. Iss. 26. Language and Human]. Saratov, Izd-vo Saratovskogo un-ta, 1996, pp. 8-14.

Sirotinina O.B. Teksty, tekstoidy, diskursy v zone razgovornoy rechi [Texts, Textoids, Discourses in Spoken Language]. Chelovek - tekst - kultura [Human Text Culture]. Ekaterinburg, Poligrafist Publ., 1994, pp. 105-124.

Tulchinskiy G.L. Gumanitarnaya ekspertiza kak sotsialnaya tekhnologiya [Humanities Expertise as a Social Technology]. Vestnik Chelyabinskoy gosudarstvennoy akademii kultury i iskusstv, 2008, no. 4 (16), pp. 38-51.

Frey A. Grammatika oshibok [Grammar of Errors]. Moscow, URSS Publ., 2006. 304 p.

Shcherba L.V. O troyakom aspekte yazykovykh yavleniy i ob eksperimente $\mathrm{v}$ yazykoznanii [On Threefold Aspect of Language Phenomena and on the Experiment in Linguistics]. Yazykovaya sistema $i$ rechevaya deyatelnost [Language System and Speech Activity]. Leningrad, Nauka Publ., 1974, pp. 24-39.

Ivanchenko G.V., Leontyeva D.A., eds. Ekspertiza $v$ sovremennom mire: ot znaniya $k$ deyatelnosti [Expertise in the Modern World: from Knowledge to the Activity]. Moscow, Smysl Publ., 2006. 454 p. 


\section{Information About the Author}

Svetlana V. Ionova, Doctor of Sciences (Philology), Professor of Department of Russian Language and Documentation Studies, Volgograd State University, Prosp. Universitetskiy, 100, 400062 Volgograd, Russian Federation, sionova@mail.ru, http://orcid.org/0000-0001-6361-741X.

\section{Информация об авторе}

Светлана Валентиновна Ионова, доктор филологических наук, профессор кафедры русского языка и документалистики, Волгоградский государственный университет, просп. Университетский, 100, 400062 г. Волгоград, Российская Федерация, sionova@mail.ru, http://orcid.org/00000001-6361-741X. 